MANOUSOS E. KAMBOURIS

Association of Historical Studies

KORYVANTES

Athens, Greece

mekambouris@yahoo.com
902:821.14'02.09 Хомер

COBISS.SR-ID 219300620

Original research article

Received: September $21^{\text {th }} 2015$

Accepted: November $15^{\text {th }} 2015$

\title{
WARFARE IN MYCENAEAN TIMES: THE ILIAD AS A PARADIGM AND THE APPLICATIONS EMERGING FOR EXPERIMENTAL ARCHEOLOGY
}

\begin{abstract}
If read without prejudice, the Homeric poems present an unequalled wealth of information on the Bronze Age, especially regarding warfare. Much more vivid and elaborate than Egyptian and Hatti bureaucratic or commemorative/propaganda records (and the respective Mycenean/Pylean/Theban tablets) they produce information on geopolitical situation and alliances, armies size, organization and deployment, troop types, tactics, chain of command and weaponeering, meaning weapons proper, intended and possible uses, combinations, manufacture and techniques of use. Such references must be cross-examined with other literary and material evidence and representative arts and skills. But some intrinsic issues, as are the dressing of battle lines, the proper use of weapons, the fabrication of weaponry and support equipment and the implicated metallurgy, an art of the gods, need the assistance of reenactment and experimental archaeology/experimental history to be elucidated in order to obtain a more cohesive and nearer to the truth perspective.
\end{abstract}

\section{KEYWORDS: MYCENAEAN TIMES, THE ILIAD, EXPERIMENTAL ARCHEOLOGY.}

\section{INTRODUCTION}

Although the Homeric issue rages, in the Iliad the cohesion of military information makes certain that the author was contemporary, had top-quality information as tactics and injuries cannot be imagined if not experienced/witnessed and was very well acquainted with combat particulars. Although some shadows do loom in some excerpts (i.e. XIII-685); ${ }^{1}$ such inconsistencies may be due

1 XIII-685. possible Athenian corruption/forgery, as Iones are mentioned fighting in proximity with the Athenian contingent; Herodotus explains how politically sensitive this issue has been from 510 to $478 \mathrm{BC}$ for the Athenians, and it might have been to the ages-long oral transmission, as, before Peisistratic recording, the epic cycle was transmitted orally. This by no means implies it was compiled in oral form: it was compiled, however, to be orally transmitted in a world of myth, lore and legend. Conventional Archaeology provides material evidence for verification of the claim; to the same end, Experimental Archaeology offers procedures.

previously and afterwards as well. There is no mention of their leaders, kings, weapons, warriors at this extract, while there are analytical ones for all others (but the Boetians, who are mentioned elsewhere and in detail) nor any mention in the Catalogue, nor anywhere else. 


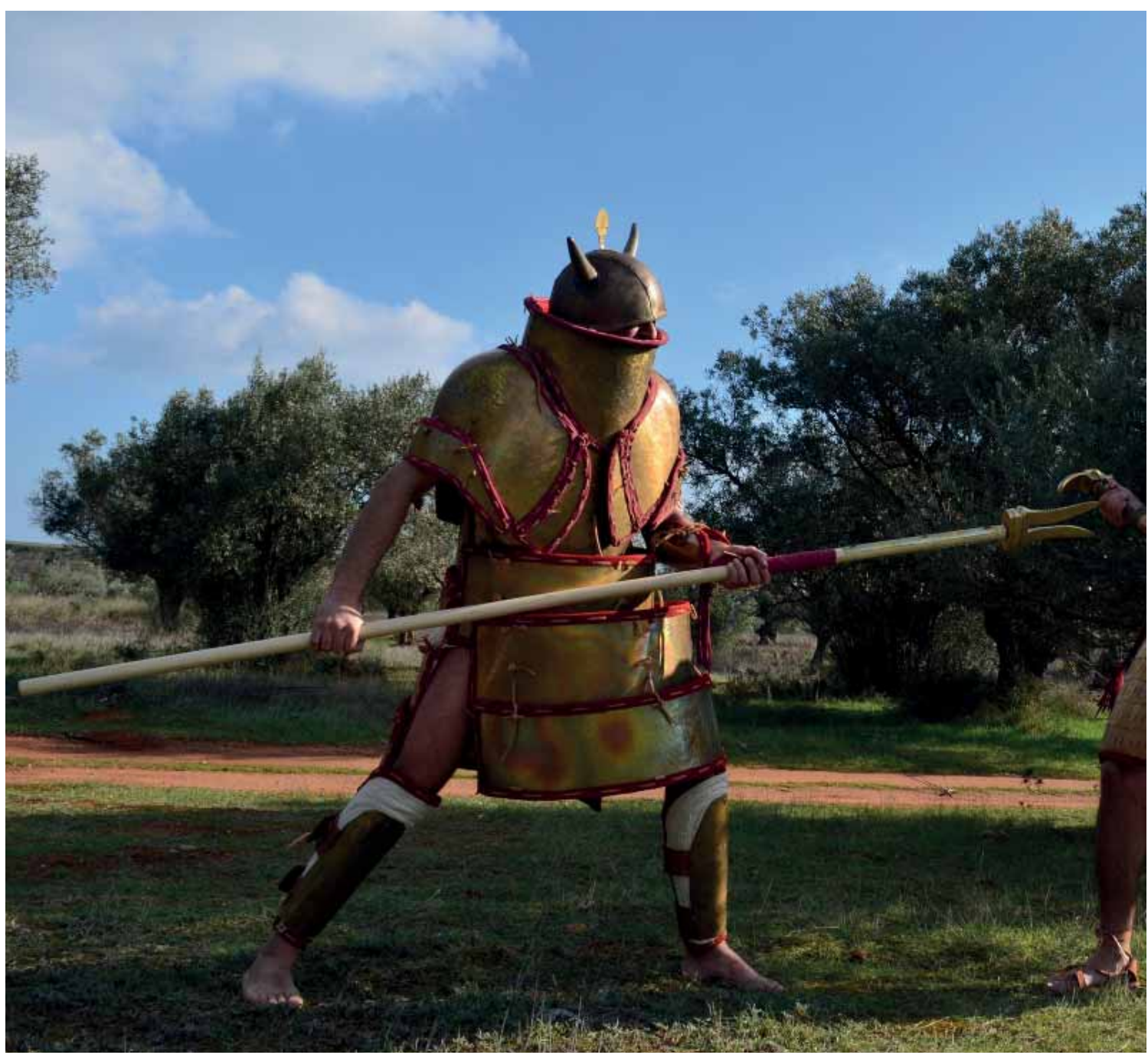

Fig. 1 Both Trojans and Greeks use from their chariots extremely long and heavy lances, perhaps the "egxeiai" of the tablets, with massive warheads reminding Japanese naginatas of the 16-17th centuries; that is for both thrusting and cutting.

\section{GEOPOLITICS}

The Homeric world is focused on two competing powers: the Mycenaean or Achaeans and the Trojans and their allies. The former were set very much from Axios river, in Macedonia, all the way to Cyprus (XI-21), with some exceptions: a part of western Greece (Acarnania-Ampilochia) did not participate due to enmity towards the high king Agamemnon, a part in NW Peloponnese, possibly the homeland of Ionians as betrayed by the name of the adjacent sea (Ionian Sea) is also vividly absent despite its wealth of archeological findings of the era (Museum of Patras), and the Cyclades Isles are not mentioned. To the contrary, the SE Aegean was securely under Mycenaean control and formed part of the campaigning force.

The Trojan confederacy was securely from the Axios River in Macedonia (II-848, XVI-287) to Lycia in SW Asia Minor (II-876), whereas its alliances were extending deep into Asia Minor, at least to the river Sagarius (III-185), from where a relative of the Trojan royal family, Assios, ${ }^{2}$ has come for assistance (XV-716). Thrace and almost

2 The name stems from Asia which today is a continent, but at the time it must have been NW Asia Minor, known as Assuwa in the tablets. 
half of Macedonia are with the Trojans, and so is the NE Aegean, with the prominent exception of Lemnos, which was turned to the Mycenaean side a generation previously and is governed by the son of Jason the Argonaut (VIII-468/70). For the big island of Chios there is no mention, nor is any for Samos and Ikaria. Contrarily, Lesbos and Tenedos were Trojan allies and stormed by Achilles at the first phases of the war (IX-129/30). Imbros and Samothrace are mentioned as islands but not as theaters of action, and their allegiance is not declared. The relations with the Levant proper are uncertain: a contingent came to help under Memnon, the king of Ethiopians and Priam's nephew, but this ethnic name even in Herodotus is used for the black population south of Egypt (VII, 69), for a similar population in India (VII, 70) and for a fragment of the cypriot contingent pointing to immigrants from the Assyrian coast just opposite of Cyprus (VII,90)- which is the best bet. Homer mentions nothing on the subject, but he does mention that Paris has sacked Sidon, the greatest Phoenician city (VII-290).

\section{ARMIES' ORGANIZATION}

There is no question that the Trojan and allied army is a feudal conglomerate under the high command of the Lord of the Hosts of Troy, Prince Hector (who might or might not have been crown prince). After 10 years behind his walls, allied contingents have arrived before his offering battle to the invaders (Othryoneus XIII-364, Asteropaios XXI-156), and continue to arrive by the day and are thrown piecemeal into battle, as they arrive (XXII-434). The basic unit are the 50 men and the size is approximately $50.000 ; 1.000$ campfires, around each 50 men sleeping, sitting or eating (VIII-558/9).

The Greek army had the same unit of 50, as the main ship is the 50-oared galley (pentekonter) of unknown model (II-720, XVI-170). Nevertheless there are some very large ships carrying 120 troops of a certain contingent (II-510); whether all of them were doubling as rowers or not is not stated. There were also 20-oared galleys for other missions (I-309). But the similarities stop there.

The Greek army is NOT a feudal levy, but an integrated organization with distinct functions. There are tactical units (Lochoi, 500-strong in Achilles' own contingent XVI-168/73). The decimal system thus implied fits well with the 10-man Oka of the tablets. During the most part of the Iliad it is indeed operating-and with little success- as a feudal levy, since Achilles, the mind and soul of the army and acting Commander-in-Chief/CiC (as indicated in XXIV-651/8 and directly stated in Odyssey iii-106) is estranged. Before the new series of clashes, described in Iliad, which happen in the 10th year of the war, the elderly tactician Nestor advises the High Commander Agamemnon to deploy the army in feudal manner (II-361/8). This means that for 9 years the army was NOT deployed in such a manner, and this differentiation is due to the absence of Achilles. Once he is back, he clearly issues all the executive directions and orders (XIX-155, XXIV-670) and the army is no feudal assembly, but an efficient war machine. Many scholars detect dramatic effect and projection in this advice of Nestor, but had it been so the poet would have easily projected it into the past, as he did in other cases, as with the pursuit of Aeneas (XX-187/91).

\section{MEDICAL CORPS}

The Greeks have a well-organized medical Corps, with two asclepiad brothers (IV-193, XI833), Machaon (surgeon) and Podaleirios (Internist). They tend both wounded and sick and are much admired and valued, but their humanity is not in question. Nothing divine or miraculous. Moreover, many a warrior, such as Achilles, Patroclus, Sthenelus and others are adequately trained in first aids and wound care, extracting arrowheads and dressing the wound (XI-830) while also 
offering analgesic medication. No such thing with the Trojans. There the Gods, within their temples or ad hoc offer miraculous treatment (XVI-528, $\mathrm{V}-447 / 8$ ), implying that the healthcare is at the hands of the priesthood, mostly of that of Apollo, the patron deity par excellance. The best a Trojan noble or follower can do is to bandage a wound with a woolen strip, (Agenor was well-provided with a number for such an emergency and used it on Helenos) to stop the bleeding or any major mechanical deterioration (XIII-599/610).

Both armies are based on the heavy armed and armored noble warrior, owning a chariot and fight-

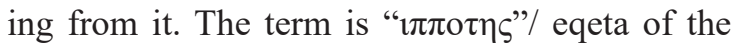
tablets. The armor of such nobles is plate bronze or copper, but the mention of "copper tunic" (XIII-439) for one -rather elder-Trojan implies also a scaled body panoply. Greeks use greaves (XI-17) and this is an item which characterizes them both in frescoes and within the Iliad. Their greaves are characterized as well-made, white and in some cases special attention is given to their attachment around the ankle, which might imply something elusive, undetected in the frescoes. On the contrary, Trojans are seldom mentioned to using greaves (i.e. Paris against Menelaus III330/1). The warriors combine heavy armor with mobility; both Achilles and Hector are fleet of foot, excellent charioteers, big of stature and very strong, epitomizing the heroic concept of "tall, strong and brave" adding the "fast".

Other heavily armored warriors in both sides are also notoriously fast: the Greek Antilochos who is an accomplished charioteer, and the wily Odysseus, who has no chariot (not to mention the lightly armed Ajax the Lesser). From the Trojan side, Aeneas, Glaukos and Paris, all of them also possessing chariots, as Troy is known for its horses. The heavily armed and excessively trained warriors dismount from their chariots to fight on foot, and are supported by chariot runners in the Egyptian manner (they are implied twice for the Trojans, one being the prince Polydoros; the other case being better attested in XV-516) and rank and file infantry, while the chariot proper awaits nearby with the driver at the ready to extract them from the fray or to allow a hot pursuit. The Trojans have better chariotry: some of their allies use two-horse teams (V-195), but some of the Trojans have four-horse teams (Hector himself mentioned specifically and by name of the horses VIII-185); whether in two tandem pairs or four abreast it is not known. The Greeks have two horse teams (XXIII-290/305), and Achilles uses a third horse (XVI-149/53) not to drag the chariot, but to make the turns swifter.

Both Trojans and Greeks use from their chariots extremely long and heavy lances, perhaps the "egxeiai" of the tablets (Figure 1), with massive warheads reminding Japanese naginatas of the 16-17th centuries; that is for both thrusting and cutting. Hector is specifically mentioned as holding a 11-cubit such chariotry lance at VIII-494 (Ajax bears a long naval spear, 22 cubits in XV678) while on chariot; he is also mentioned to pursuit the Greek rank and file ${ }^{3}$ on chariot, thrashing heads (XI-309) and wielding his spear. This adds up to the aforementioned weapon. Most obviously, this is also the nature of the great spear donned to Achilles by his father, which could not be wielded by anyone else (XVI-140/3). So heavy a weapon might not be a javelin or anything light enough for casting. It is not accidental, that the Greeks considered lanced chariotry fighting in jousts (as Nestor advocates, IV-306/7) a thing of the past; Nestor, the Elder, is synchronous with the apex of such practice, as had been the father of Achilles. But, for dismounted fighting, the lance may prove impractical. For this reason the warrior is always equipped with a general purpose spear, for casting and thrusting alike, and generally carried in pairs

3 Armed either as medium infantry, with helmet, spear, shield, sword XIII-714/5 or as prescribed in the Odyssey, where "armed for war" means at the very least two items: spear(s) and body shield; helmet might be included in the basic kit, but no sword nor greaves are essentials and might be reserved for better armed troops. 
(VI-104, XIII-559). This reminds us of the very later Persian "palta" of the cavalry, much praised by Xenophon. The pair of spears is mentioned many a time Hector jumps out of his chariot, and this might imply that he changes weapons, from lance to spears. It is obvious that both lance and spears are routinely secured within the chariot. An excellent example is Patroclos who sets out with two spears in XVI-139 but after casting one to Sarpedon's mate and never recovering it he is explicitly mentioned as fighting hencewith with one (XVI-733, XVI-801), which he does not cast and for missile he reverts to stones while having the spear at his left hand. In another very enlightening excerpt (XIII-559), Antilochos, son of Nestor (a master charioteer in XXIII-306/8), is mentioned as fast, agile and always eager to fight, either casting from afar, or charging at contact. In both cases the spear is the main weapon, which vividly illustrates the merit of the two-role "dory" which can be thrown or thrust and is carried in pairs. What is of importance, is the fact that Pandaros, one of the very few Trojan allies who came on foot because he doubted the adequacy of fodder for his (twohorse) teams, has taken his bow INSTEAD; his phrasing points to the bow being mutually exclusive with charging chariotry (V-192/210), much unlike the Egyptian practice-but perhaps consenting to the one of Hittites.

Moreover, the Greeks have many first-line heroes and kings who do not possess or use a chariot. Some do fight the heroic way, an agile skirmishing fight with javelin and heavy armor (Odysseus), while others (both Ajaxes) fight in a way unsuitable to and incompatible with chariotry, although from close range. Thus, the Greek army has more troop types than the Trojans, who have medium infantry, runners (XV-516), archers and heavy charioteers (knights). The Trojan archers might fire from within the ranks as did Pandaros (IV-114), covered by shields, or individually. It is a fact that they may fire en masse, volleys, especially from their walls; the latter is stated, the former not really but the conjecture is secure.
It is very strange that the Greeks, who despise the weapon, have also competent archery skills. The troops of Philoktetes are good archers and may fire individually (II-720), Teukros exemplifies the pair of heavy shield-bearer-archer (VIII265/70) with his brother Ajax the Great although he may fight with spear and shield, as medium (armed with helmet, spear, shield, sword XIII$714 / 5$ ) or heavy infantry, whereas the Locrian contingent fires en masse from a distance (XIII$716 / 22$ ), shirking contact and shooting some Trojan assaults to pieces from behind the storm troops' lines. Except medium infantry, chariotry and missile troops, that is archers, the Greeks also have heavy shielded infantry for static defense, a commodity never implied for the Trojans. The personification is Ajax the Great, a very tall and strong warrior, the second in valor and merit to Achilles, but never accused as fleet of foot nor seen to mount a chariot. His resolve, steadfastness and endurance are admirable. He is supported by either his brother Teykros, the archer, or another chariotless king, the Locrian chieftain Ajax the Lesser. Although his contingent is archers only, Ajax the Lesser is storm trooper, but definitively light infantryman, as he substitutes metal armor with linen corselet (II-529). He is very fast, an excellent spearman and offers to Ajax the Great's stability a skirmishing support (XVII-719/21) and a destructive power of pursuit (XIV-520/1), more or less exposing the combined tactics of the integrated Greek army.

\section{TACTICS}

For army tactics, Achilles favors charge and clash (XX-354/5); this is not always the choice of neither commander, who may stop at a distance and exchange missile fire (XV-710), as did the European armies of the 16-18th centuries, while skirmishers, usually the well-protected nobles, may jump in between opposing armies and strike targets of opportunity as exemplified by Antilochos 
(XIII-559). After a prolonged exchange which has softened up the one opponent, the other one charges (XI-85/90). The reason for avoiding the clash from the first encounter is obviously the lying of the advantage with the offensive weapons; thus rushing to contact with a large and expedient in missile warfare enemy body is ill-advised. Shields and armor are more often penetrated than not. Menelaus, an important and powerful and wealthy king is hit by an arrow and wounded after the arrowpoint (which is explicitly mentioned as "iron" IV-123) pierces three successive armor parts (IV-133/5); such a succession of armor is indicative of Dendra-type armor and would not have been found in other body parts, which would have been pierced more easily. But the same corselet staves off Helenos' arrow from point-blank (XIII585/95). Only Achilles (with armor made by a God) suffers no penetration-his greave even staves off a direct spearcast (XXI-591/4). But he himself is not very confident on the subject (XX-261/5). Despite this fact, he chooses to strike Hector in a spot not covered by his own, captured armor: as the latter charges leaning forward, Achilles thrusts at the joint of neck and shoulder (XXII-322/6). Although panoplies are routinely penetrated, the thing is different with the shields. Archery is not mentioned to pierce shields. Most lethal spearcasts and thrusts are delivered around shield coverage, to the body armor or to unprotected body parts. Few hits on armor are repulsed, in cases resulting in broken spearpoints or even spears-but the latter is considered a god-sent strike of misfortune (VI-306, XIII-564/5) (most probably a failed -and flawed in manufacture-weapon). Shields, on the other hand are just as often pierced as they repel the points (Ajax's and Achilles' shields are never pierced). Helmets are routinely giving way under direct hits and blows, but are also responsible for some spectacular saves: Hector, Paris, Menelaus are saved by spearcast, swordcut and straight-axe blow respectively (XI-350, III-362, XIII-615).

Greeks have very tight phalanx formations (XIII-129/131, XVII-352/65); the Trojans can- not do the same, nor break them. It is an issue whether this is due to the shields used or to any other factor. Tower shields are not mentioned for Trojans, who do use 8-body-shields, as do many Greeks; Hector has a body shield which demands dexterity in moving and handling (VII-238/9) and when thrown back it is felt at heel and neck while running (VI-118); and he is no exception, but the rule. It is described also as symmetric (XI-61, VII-250) (not meaning circular, as interpreted, but 8-figured). Both enemies use round shields. There might also be double-grip shields, as in Pylos frescoes, reminiscent of argive shields. The tower shield mentioned is the one of Ajax the Great. Homeric language is inconsistent, but it is the only one that might be called "sakos", as the greek term implies something rectangular-ish, which is not the figure of 8 or the eclipse or the round shields.

Body - shield-bearers, armed with extra-long lances (egxeiae) were most probably NOT deployed in tight phalanx. First, being able to get INTO the shield is important when NOT in phalanx. In phalanx, enough to go behind the shield, as hoplites would show some centuries later. A close phalanx would have been crushed by the leading teams of chariotry, especially if supported by powerful and accurate missile fire. An open deployment, however, would expose body-shield bearers them to runners and light infantry. The fresco of Thera, showing a dispersion which allows motion so as to avoid being trampled by the chariotry, while the length of the lances permits to support a comrade from light infantry swarms, is perhaps a more viable paradigm. The dispersed troopers do not offer a solid target for massive archery but must be picked one by one, which is tricky if they are not in even spaces and straight lines and files. The spears offer crossfires, and evasion of charging chariots while lancing at the team or the crew is possible. The concept is still viable if lance is substituted for spear, and archers can be dispersed within the formation. The shorter spear might turn the formation a bit denser, but 
not too much; this might be the Homeric paradigm for both opponents.

The Greek dense phalanx is clearly depending on three things (XIV-371/82): men (must be heavy and strong, not light and agile), shields and spears. Longer spears are better suited for porcupine formations and it is very probable that explicit reference to spearfighters in both armies implies use long spears- rather lances "egxea"- instead of the more typical "dory" double-use spear which was the current standard and is seen in Thera's fresco arming light infantry. For the Greeks the best case-study is the contingent of Avantes, while a Thracian contingent is the respective from the Trojan side (IV-533). It is explicitly mentioned for Avantes that their spears break through cuirasses (II-543/5) and armor; thus they are special weapons compared to standard "dorata". But the heart of the issue lies with the shields: Homer mentions partial redistribution of weaponry (unevenly issued as a result of conscription practices, a millennia-old problem) to have the heavy shields in front, to shield a phalanx (XIV-376/7). This is not necessarily correct: the lighter shields, termed «laiseia»(V-453) and being either the Warrior Vase reverse crescent copper-faced models, or circular ones, either one-handled (as the Herzsprung example) or two-handled, as in Pylos frescoes, allow denser packaging; and denser packaging of men means a more threatening and repulsive wall of spearheads (as shown by the Macedonian phalanx, which, according to Diodoros, just brought back to life the Homeric phalanx), which clearly intercepted Hector and the Trojan onslaught (XIII-145).

The last issue on greek tactics is the "tower" (IV-334), an effective offensive but not defensive formation. It must have been similar to $19^{\text {th }}$ century columns used by the Napoleonic French infantry for prompt assault minimizing exposure to line fire and giving momentum in the collision. The rationale should have been similar in the bronze age and a kind of drill would allow transformation of infantry units.
The Trojans, with their intimate knowledge of the peculiarities of land, space and weather, seem to follow Sun Tzu and use such conditions proficiently. Their attacks under low visibility due to fog, mist and wind (XV-668/70, XVI-645/50) in the "Windy Ilion" caused much distress to the Greeks, who are better performing in good visibility, due to numbers and perhaps tactical efficiency. Both opponents are more or less considered capable of expedient and massive kindling of fire for offensive use against enemy positions, ships or cities- a near fatal inability of the Athenian army at Marathon $(490 \mathrm{BC}$ where they could not burn Persian ships and had to capture them, resulting in just 7 prices-out of some hundreds).

It might have been a Trojan tactic to aim for the legs facing heavy opponents. The proverbial "Achilles' heel" is not an isolated incidence. In XI-379 Paris' arrow nails Diomedes' foot to the ground by hitting the ankle. It might be more of skill and intention and less than luck to hit two prominent heroes at the same spot, heroes with highly regarded armor (and one of them having survived a direct hit of an iron-tipped arrow at the cuirass (Diomedes, when hit by Pandaros in V-99). Last, Agenor shot his spear at Achilles' shin (XXI591), which is the same concept-or even a slight miss, if he aimed for the ankle and foot and missed his precise mark as Achilles charged forward.

\section{EXPERIMENTAL ARCHAEOLOGY - EXPERIMENTAL HISTORY}

There are many issues in the above observations. Some focus on "how was that done" and others on "is this possible?". The ability to do it today in reenactment or simulation proves positively that a procedure is attainable. It does not prove that the ancients did it in this way. And if today we cannot do it, the negative value of the simulation is limited. They knew better....

Some things are just a matter of sweat. Issues can be simply tried by teams in a field. The way 


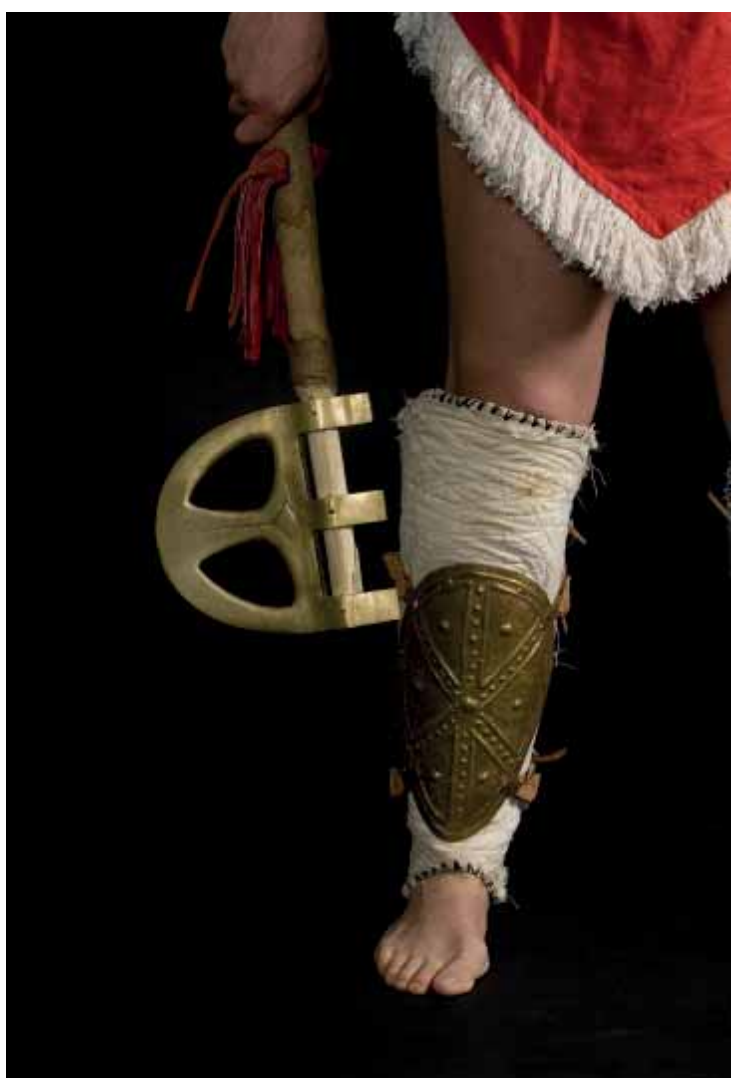

Fig. 2 What is the metal for the greaves? Are they copper/ bronze/brass? The Greeks are mentioned as "having white greaves" or as having "nice greaves".

in which standard shield-bearers, armed with extra-long lances (egxeiae) were deployed is one of such problems. A close phalanx would have them crushed by the leading teams of chariotry. An open deployment would expose them to runners and light infantry. The fresco of Thera, showing a dispersion which allows motion so as to avoid being trampled by the chariot, while the length of the lances allows mutual support in cases of from infantry swarms, is a nice subject for experimentation.

The way the heroes chased after their cast spear using the force of the cast to follow, not to recoil as today's athletes, in order to either retrieve the weapon or to continue the attack with the sword (as does Menelaus against Paris and Achilles against Aeneas) before the initiative is seized by the opponent is another interesting issue (in XIII-512 Idomeneus was considered too mature to be capable of executing the drill). This practice is highly reminiscent of current protocols for air combat by fighter pilots, who engage the enemy successively using the longer-range weapons to gain time and advantage as they close in for shots with shorter range ones. In this case the "DD", the "duel dance", which means the almost standardized procedures in homeric duels which, though, had tactical meaning, may be validated mainly by reviving and reenacting such moves with realistic weaponry. The use of secondary weapons is important, after the spear is cast or broken: there is one mention of the straight axe, in Trojan ally's use (XIII-612 $\alpha$ šiv $\eta$ instead of " $\pi \dot{\lambda} \lambda \varepsilon \kappa v \varsigma " /$ regular axe for tree falling in XXIII-115) and then a direct mention of both straight and conventional axes (XV-710).

The usual choice is the sword. Homeric terminology is inconsistent, but one can discern the very long, thrusting weapon (fasganon in Homer, pakana in the tablets) and the sturdy, double use "aor", which chops limbs and heads (XX-481) and is bulged near the point ("oarlike" XV-713, $\mathrm{XX}-475)$. A distinguished such weapon is mentioned as being of Thracian origin, imported to Troy for prince Helenos (XIII-576). Archers are equipped with swords if they are of heroic status. In Homer, though, swords often break. It is experimental archeology which might identify the flimsy ones with the thrusting fasgano instead of the heavy aor. Though, during the middle ages the main kind of straight sword was triangular and long; despite this fact they were excellent cutting weapons, and it might well be the same with fasganon- only robust modeling, simulation and experimentation might prove each side's merits (apart from the obvious, to kill someone through a bodyshield-which might have been the reason for copper-covered bodyshields in Iliad, which are not mentioned in Odyssey).

But other issues need different approaches, and other cases need more elaborate skills, schemes and equipment.

Can there be a bow made of horn as is stated for Pandarus? The issue is not if the Scythians, the English or the Mongols did it otherwise. Is it pos- 
sible? In 2014 the American bowmaker Jack Farrell (https://www.facebook.com/jack.farrell.794/ posts/10202864416985661) presented one such item. On the other hand, as with the shield of Achilles, a technological secret may be wrongly perceived due to the common name (bow made of horn-implying that it is not just of wood, as usual ones, but horn has been used, too-though not exclusively). Poets are not technicians-although they might be surgeons or warriors or even farmers and herders. Thus technical details are not their strong point. What is much more easy to approach is the technique: Pandaros is mentioned (IV-121/3) to draw to the chest, less and lower than the English/ Welsh longbow practice to the ear. He draws both arrow and string, and the arrow has carved edge to provide a better grip, not slipping due to sweat, blood or water

What is the metal for the greaves? Are they copper/bronze/brass? The Greeks are mentioned as "having white greaves" or as having "nice greaves" (see Figure 2). The latter is never used for Trojans; they may be assumed not to use them. But the white argive greave, is it painted? What is the metal of Achilles' ones, which staved off a direct spear-cast (XXI-558)? Tin (mentioned as the metal of manufacture in XXI-558) does not convince. Is there any other, white metal?

Are we right to suppose the weapons of the era were not of copper but of bronze? Copper is not durable, but this is for pure copper. The mines of Greece do not produce very pure copper and the admixtures of the native copper ore provide readily a rather robust product. Are there any spectral analyses of findings, to see whether tin was such a strategic metal after all? Or was it mostly used for cooking pans, to avoid copper poisoning? Greek helmets from the classical era are green-rusted, and some even show blue rust patches. The helmet of Miltiades is green-rust after 2500 years; a Persian helmet taken from the same battle as a prize, and kept at the same museum, is yellowish as if used last year.

Attacking through the fog and mist or with the wind on the back would be easy for a native host. The prompt kindling of fire to prepared torches for the moment the enemy ships would be reached upon is also rather simple. But what is to make of the pinpoint accuracy with which Diomedes is assaulted by lightning bolts- which defy natural laws and instead of Ozon smell of Sulfur? Patroclus was disarmed by Apollo's strike on his back and the description is reminiscent of a blast (XVI790/806). As a result his spear is broken, his shield and armor blown away and he emerges stunned and disoriented; much like the victims of $17^{\text {th }}$ century grenadiers. Moreover he emerges through a cloud: was it dust from a windburst or smoke from a blast explosion? With the known ingredients of the period can one be too bold to assume the use of black powder, which is easy to make and smells of sulfur, while producing the noise of the thunder? Does this have something to do with the appeasement of the priests of Athena (the Goddess of Inventions) in Troy by Hector's seer-brother Helenos? It is not very original. The Thebans most probably had used it on Sthenelus's father, Kapaneus, thus claiming victory a generation earlier.

A martial art with weapons is implied in Achilles' rampage (XX-455/89) and in Tudeus killing an impressive 49 out of 50 ambushers (IV-393).

The ultimate experimental goal would be the restoration of the composition of the shield of Achilles. In here there is metallourgy, the disdained art. Homer writes that copper, tin and gold where used in 2/2/1 ratio (XX-270/2) and believes that this means layers or plates. Is this so? In such case, what was the order? Gold was in front, at the back or in the middle? If in the middle, the layers of copper and tin where palindromes or tandem? And what if it is NOT so? Even the best scribe and poet might not understand that these are the necessary ratios for forming an alloy, instead of using the ingredients in successive layers. Do we have anything to learn from this process as far as armoring and protection from kinetic energy threats (not only in war, but also in urban and industrial accidents) are concerned? 


\section{BIBLIOGRAPHY}

Arnold, J. R. 1982

A Reappraisal of Column Versus Line in the $\mathrm{Na}$ poleonic Wars, Journal of the Society for Army

Historical Research LX no. 244.

Bossert, H. T. 1946

Asia. Literarische Fakultat der Universitat Istanbul no. 323, Forschungsinstitut fur altvorderasiatischeKulturen no. 2, Istanbul.

\section{Castleden, R. 2005}

The Mycenaeans, Routledge.

\section{Chadwick, J. 1976}

The Mycenean world, Cambridge: University Press.

Doumas, C. 1992

The Wall-Paintings of Thera, Thera Foundation.

Lejeune, M. 1968

La civilization mycenienne et la guerre. In Vernant J-P Problemes de la guerre en Grece ancienne, Paris: Ecole des Hautes Etudes Anciennes Sociales.

Liddell H.G. \& Scott R. 1889

An Intermediate Greek-English Lexicon, Clarendon press.

Shaw R. L. 1985

Fighter Combat Naval, Institute Press.

Ventris, M. \& Chadwick J. 2015

Documents in Mycenaean Greek, Cambridge:

Cambridge University Press.
REZIME

RATOVANJE U MIKENSKO DOBA: ILIJADA KAO PARADIGMA ZA PRIMENU U EKSPERIMENTALNOJ ARHEOLOGIJI

\section{KLJUČNE REČI: MIKENSKI PERIOD, ILIJADA, EKSPERIMENTALNA ARHEOLOGIJA.}

Za Homerovu poeziju možemo reći da predstavlja najiscrpniji izvor informacija o bronzanom dobu, naročito onom segmentu koji se odnosi na ratovanje. Ona je daleko životnija od egipatskih zvaničnih zapisa ili spomen ploča koje su imale propagandnu funkciju ili mikenskih i tebanskih tabli. Homerova poezija pruža informacije o geopolitičkoj situaciji i savezima, veličini vojske, organizaciji i rasporedu vojske, trupama, lancu komandovanja i naoružanju, oružju i njegovoj nameni, proizvodnji i tehnici korišćenja. Uz to treba dodati da podatke dobijene iz Homerovog speva treba unakrsno ispitivati sa drugim literarnim izvorima i materijalnim dokazima, kao i reprezentativnim umetničkim delima. Međutim, pojedini specifično vojni problemi kao što je postavljanje borbene linije, pravilna upotreba oružja, proizvodnja oružja i opreme i povezanost sa metalurškom proizvodnjom, zahteva pomoć eksperimentalne arheologije, koja treba da rasvetili određeni period u cilju dobijanja što koherentnije i istinitije slike prošlosti. 